\title{
PROBLEMATIKA DAN SOLUSI DIKOTOMI ILMU DI INDONESIA
}

\author{
Anggun Wira Puspita \\ IAIN Samarinda \\ Email: puspitaanggun704@gmail.com
}

\author{
Rina Muda Siraturrahmah \\ IAIN Samarinda \\ Email: rinamuda27@gmail.com
}

\section{Muhammad Khairul Rijal}

IAIN Samarinda

Email: rijalforza@gmail.com

\begin{abstract}
Abstrak
IImu adalah suatu pengetahuan tentang suatu bidang yang disusun secara bersistem menurut metode tertentu yang dapat digunakan untuk menerangkan gejala tertentu dibidang tersebut. Secara etimologi, ilmu berasal dari bahasa arab dari kata ilmu yang berarti memahami, mengerti, atau mengetahui. IImu bukan hanya sekedar pengetahuan berdasarkan teori-teori yang disepekati dan dapat secara sistematik diuji dengan seperangkat metode yang diakui dalam bidang ilmu tertentu. Ditinjau dari sudut filsafat, ilmu terbentuk karena manusia berusaha berfikir lebih jauh mengenai pengetahuan yang dimiliknya. Agama adalah sistem yang mengatur tata keimanan dan peribadahan kepada Tuhan yang Maha Esa serta tata kaidahnya berhubungan dengan pergaulan manusia dan lingkuungannya. Dengan adanya dikotomi dalam ilmu pendidikan membuat pendidikan semakin terpisah-pisah sesuai dengan ilmu yang berkenaan. Dan pemisahan ilmu umum dan ilmu agama ini membuat pemikiran negatif disuatu pihak yang lebih condong di ilmu agama sendiri ataupun ilmu umum. Tujuan dari penulisan ini untuk membahas masalah dan solusi yang disebabkan oleh adanya dikotomi itu sendiri untuk mencapai suatu pendidikan yang memiliki visi dan misi tanpa sistem pengelompokkan sesuai disiplin imu.
\end{abstract}

Kata Kunci: ilmu, agama, dikotomi

\begin{abstract}
Science is a knowledge of a field which is arranged systematically according to certain methods that can be used to explain certain symptoms in that field. Etymologically, science comes from the Arabic Language from the word 'ilm' which means to understand or know. Science is not merely knowledge based on agreed theories and can be systematically tested with a set of methods that are recognized in a particular field of science. In terms of philosopy, science is formed bbecause human tray to think further about the knowledge they have. Religion is a system that regulates the rules of God Almighty and it's rules of association relate to human association and it's enviroment. With the relevant knowledge. And the separation of general science and religious science make negative thinking on the side of those who are more inclined in their own religious or general science. The purpose of this paper is to discuss the problems and solutions caused by the dichotomy itself to achieve an education that has a vision and mission without a grouping system accordingto the dicipline science.
\end{abstract}

Keywords: science, religion, dichotomy 


\section{A. Pendahuluan}

Dikotomi dalam bahasa Inggris adalah dichotomy yang berarti pembagian dalam dua bagian, pembelahan dua, bercabang dalam dua bagian. ${ }^{1}$ Ada juga yang mendefinsikan dikotomi sebagai pembagian di dua kelompok yang saling bertentangan. ${ }^{2}$ Secara terminologis dikotomi dipahami sebagai pemisahan antara ilmmu agama dengan ilmu umum yang kemudia berkembang menjadi fenomena dikotomik-dikootomik lainnya, seperti dikotomi ulama dengan intelektual, dikotomi dalam dunia pendidikan Islam dan bahkan dalam diri muslim itu sendiri (split personality). ${ }^{3}$ Dikotomi secara terminologis juga berarti dualisme religius dengan kultural. $^{4}$

Dalam penerapannnya, disebutkan sebagai ilmu umum dan ilmu Islam, pendidikan umum dan pendidikan Islam, guru pendidikan umum dan guru pendidikan Islam, sekolah umum dan sekolah Islam. Dengan ini, dikotomi ilmu yang dimaksud di sini adalah pembagian dua kelompok ilmu pengetahuan, secara lahiriyah kelihatan bertentangan, yang di akui bahwa ilmu agama berasal dari Islam, sedangkan ilmu umum diklaim berasal dari Barat. Pemisahan ilmu dalam dunia pendidikan menjadi ilmu umum dan ilmu agama telah mengantar dunia pendidikan di Indonesia menjadi suatu pendidikan yang menghasilkkan ilmuwan-ilmuwan yang tidak bertanggungjawab tehadap kehidupan kemasyarakatan dan lingkungan. Dan pendidikan agama yang terlalu memisah dari ilmu-ilmu sosial dan humaniora telah melahirkan ahli-ahli agama yang tidak peka terhadap kehidupan sosial dan cenderung buta di zaman modern. Pola pikir yang serba bipolar-dikotomis ini menjadikan manusia terasing dari dirinya sendiri, terasing dari keluarga dan masyarakat sekelilingnya, terasing dari lingkungan alam dan ragam hayati yang menopang kehidupannya, serta terasing dari denyut nadi lingkungan sosil-budaya sekitarnya. Yang akhirnya terjadi proses dehumanisasi secara massif baik pada tataran kehidupan keilmuan maupun keagamaan. ${ }^{5}$

Kondisi di atas disebabkan adanya keyakinan dalam masyarakat bahwa agama dan ilmu adalah dua entitas yang tidak bisa dipertemukan. Keduanya mempunyai wilayah sendiri, yang terpisah antara satu dan lainnya, baik dari objek formal maupun material, metode penelitian, kriteria kebenaran, peran yang dimainkan oleh ilmuwan maupun status teori masing-masing bahkan sampai ke institusi penyelenggaranya. Ilmu tidak mempedulikan agama dan agama tidak mempedulikan ilmu. ${ }^{6}$

Adapun kaum skeptic yang mengklaim agama jelas-jelas tidak dapat membuktikan kebenaran ajaran-ajarannya dengan tegas, padahal sains bisa melakukan hal tersebut. Agama bersikap diam-diam dan tidak mau memberikan petunjuk bukti kongkrit tentang keberadaan Tuhan. Di pihak lain sains mau menguji semua hipotesis dan semua teorinya berdasarkan "pengalaman". Agama tidak bisa melakukan hal tersebut dengan cara yang bisa memuaskan pihak yang netral. ${ }^{7}$ Lebih jauh mereka sering mengatakan bahwa agama dilandaskan pada asumsi-asumsi apriori atau keyakinan. Sedangkan sains, tidak mau menerima begitu saja segala sesuatu sebagai benar. Selain itu agama

\footnotetext{
1 John,M, Echols dan Hasan Shadily, "dichotomy", Kamus Inggris-Indonesia (Jakarta: PT. Gramedia Utama,2007)hlm,180

2 Departemen Pendidikan Nasional, Kamus Besar Bahasa Indonesia, edisi keempat (Cet, 1: Jakarta: Gramedia Pustaka Utama,2008), hlm,205

${ }^{3}$ Ahmad Watik Pratiknya, Pendidikan Islam di Indonesia Antara Cita dan Fakta, (Yogyakarta:

Tiara Wacana, 1991),hlm,104

${ }^{4}$ Isma'il Raji al-Faruqi, Islamization of Knowledge: General Principles and Workplan, (Hemdon: HIT,1982),hlm,37

${ }^{5}$ Amin, Abdullah dkk,Menyatukan Kembali Ilmu-ilmu Agama dan Umum: Upaya memperrtemukan Epistemologi,(Yogyakarta: SukaPress,2003) hlm,4

$6 \mathrm{lbid} \mathrm{h} / \mathrm{m}, 3$

${ }^{7}$ Haught, Perjumpaann Sains dan Agama: Dari Dialog ke Konflik, (Jakarta: Mizan,2005)hlm,2
} 
terlalu bersandar pada imajinasi liar, sedangkan sains bertumpu pada fakta yang dapat diamati. Agama terlalu emosional dan penuh gairah, dan subjektif, sedangkan sains berusaha untuk tidak memihak, tidak terlalu bergairah, dan objektif ${ }^{8}$

Jadi, penulis dapat menyimpulkan dari pernyataan-pernyataan diatas bahwa ilmu umum dengan ilmu agama itu sama-sama ilmu tetapi memiliki perbedaan dalam membahas bidang ilmu. Dan dikotomi ilmu ialah suatu sistem yang memisahkan ilmu agama dengan ilmu umum menjadi dua ilmu yang bertentangan yang tidak dapat menyatu dikarenakan suatu perbedaan ilmu dan perbedaan naungan. Dan dapat membuat batas antara ilmu dunia dan akhirat. Yang seharusnya dua ilmu dunia dan akhirat yang dapat saling membantu dan mempedulikan ilmu satu dengan yang lain.

\section{B. Pembahasan}

Sebagaimana telah dibicarakan bahwa dikotomi pengatahuan merupakan proses sejarah yang membudaya dalam kehidupan ummat islam. Di sini, dikotomi muncul dari konteks ruang waktu dan jalin kelindang kehidupan umat islam dalam kurun waktu tertentu. Ideologi, politik, sosial, dn budaya dalam hal ini menjadi faktor yang memengaruhi munculnya dikotomi ini. Dalam perkembangan, dikotomi keilmuan ini akan menyatu terhadap model pemikiran. Di satu pihak, ada pendidikan yag hanya memperdalam ilmu pengatahuan modern yang kering dari nlai-nilai keagamaan. Di sisi lain, ada pendidikan yang hanya memperdalam problem agama yang terpisah dari perkembangan ilmu pengatahuan.

Islam adalah agama yang sempurna mencakup keseluruhan aspek kehidupan sehingga Pendidikan Agama Islam mestinya meliputi semua bidang keilmuan tanpa membedakan antara ilmu dunia dan ilmu akhirat atau ilmu umum dan ilmu agama. Hal ini paling tidak terbukti dengan turunnya ayat pertama yang berbunyi 'iqro' yang berarti "bacalah". Perintah membaca ini disampaikan sebelum adanya ayat Al-Qur'an yang lain sehingga konotasi perintah itu bisa diartikan untuk membaca ayat-ayat kauniyah yang tersebar diseluruh alam semesta ini. Dengan ini berarti pengembangan ilmu pengetahuan harusnya tidak perlu dibedakan antara ilmu agama dan ilmu umum, karena keduannya dapat melengkapi dan saling mendukung. Penggabungan inilah yang terjadi pada periode Islam klasik, bahkan pada saat kejayaan Islam semua disiplin ilmu pengetahuan dikuasai oleh umat Islam, mulai dari ilmu fiqih sampai dengan ilmu fisika serta ilmu-ilmu yang lain. Bahkan pada masa kejayaan mereka membuat karangan buku yang dipelajari dan dikembangkan di Eropa pada periode pencerahan yang kita dapat lihat sekarang.

Paradigma dikotomi ini sebenarnya dimulai pasca Mu'tazilah meninggalkan pemerintahan Islam. Dan setelah itu umat Islam mulai kurang dalam mempelajari ilmu umum dikarenakan kurang berkenaan dengan akhirat. Mereka hanya senang dan peduli pada pengembangan ilmu-ilmu yang berkaitan langsung dengan ayat-ayat Qur'aniyah dengan memarjinakan ilmu-ilmu yang berkonotasi pada ayat-ayat kauniah. Padahal kedua ilmu ini mestinya harus berjalan seimbang dan saling mendukung karena dapat dikaitkan. Kondisi dikotomi ilmu ini bertambah parah ketika umat Islam dijajah oleh bangsa Barat termasuk Indonesia sendiri yang lebih dari 300 tahun dalam penjajahan kolonial Belanda. Penetrasi Belanda ke bumi Nusantara ini mengambil bagian yang signifikan dalam mempertegas dikotomisasi Pendidikan Agama Islam. Sebab para ulama sangat membenci terhadap semua yang dibawa penjajah termasuk ilmu pengetahuan yang kemudian dikonotasikan dengan ilmu umum, sehingga semakin tegas mereka membedakan antara imu agama dan ilmu umum.

Dikotomi ilmu agama dan ilmu umum ini masih kita rasakan sampai sekarang, sehingga dalam urusan pendidikan di Indonesia pun ilmu umum menginduk pada Departemen Pendidikan Nasional yang mengurusi pendidikan umum juga Departemen Agama yang hanya mengurusi pendidikan agama. Pemisahan antara ilmu agama dan ilmu umum ini

${ }^{8} \mathrm{lbid}, \mathrm{hlm} 5$ 
berimplikasi terhadap pengembangan Pendidikan Agama Islam dipesantren yang hanya terfokus pada orientasi keakhiratan, sedangkan masalah dunia dianggap tidak penting. Adapun permasalahan dalam pemisahan ilmu yaitu, sekolah agama telah terkotak dalam kubu sendiri, maksudnya ialah sekolah agama memiliki induk yang berbeda dengan sekolah umum. Sumber masukan sekolah agama dan perguruan tinggi Agama Islam rata-rata dipandang belum mampu, maka mutu tamatannya digolongkann menjaddi kelas dua karena ilmu yang dipelajari adalah ilmu agama yang hanya berorientasi pada akhirat saja tanpa ilmu umum yang berorientasi pada dunia. Hal ini dikarenakan mereka salah dalam memahami hadis :

"Dunia adalah penjara bagi mukmin, dan surga bagi kafir" (HR Tirmidzi).

Sehingga mereka sangat apatis terhadap urusan dunia dan ilmu-ilmu yang terkait dengan keduniaan. Dalam hadis di atas sebenarnya bermaksud tentang kenikmatan dunia yang hanya sangat terbatas seperti halnya kesengsaraan dalam penjara jika dibandingkan dengan kenikmatan akhirat yang tak terbatas. Pengaruh-pengaruh negatif dari adanya dikotomi Pendidikan Agama Islam ini sehingga perlu ada upaya untuk memulihkannya sebagaimana yang terjadi pada Periode Klasik, di mana Pendidikan Agama Islam mencakup keseluruhan bidang keilmuan tanpa adanya pemisahan yang berbeda antara ilmu agama dan ilmu umum. ${ }^{9}$

Berdasarkan rumusan Undang-Undang Sistem Pendidikan Nasional RI No.20 tahun 2003 pasal $3^{10}$, yang mengemukakan bahwa tujuan pendidikan Indonesia mengarahkan warganya kepada kehidupan yang beragama, sebagai bentuk penerapan yang nyata dari UU Sisdiknas tersebut, Integrasi adalah alternatif yang harus dipilih untuk menjadikan pendidikan lebih bersifat menyeluruh. Gagasan integrasi (nilai-nilai agama dan umum) ini bukanlah sebuah gagasan untuk meraih simpatik akademik, melainkan sebuah kebutuhan yang harus dijalankan sebagai pedoman pendidikan yang ada. Karena pendidikan selama ini dipengaruhi oleh dualisme yang kental antara ilmu-ilmu agama dan ilmu-ilmu umum, tetapi upaya untuk mengintegrasikan ilmu pengetahuan umum dengan nilai-nilai agama harus tetap diusahakan tanpa adanya pengelompokkan.

Tujuan dari pendidikan nilai pada dasarnya untuk membantu mengembangkan kemahiran berinteraksi pada tahapan yang lebih tinggi serta meningkatkan kebersamaan dan kekompakan. Tujuan pendidikan nilai ini tidak dapat tercapai tanpa aturan-aturan, indoktrinasi atau pertimbangan prinsip-prisnip belajar. Namun sebaliknya, dorongan moral dan komponen pembentukan struktur itu sangat penting. Oleh karena itu, pendidik seharusnya tidak hanya sekedar membekali dan menjejali peserta didik dengan pengetahuan tentang tujuan serta analisis dari hubungan antara tujuan dengan alat.

Maka dari itu adapun solusi untuk dikotomi ilmu di Indonesia, pertama, melaksanakan pembelajaran secara efektif dan efisien yang mengintegrasikan nilai-nilai agama Islam dalam mata pelajaran umum. Seperti yang diterapkan di madrasah tak hanya ilmu agama saja namun ilmu umum pula. Kedua, Meningkatkan penghayatan serta pengamalan nilai-nilai keimanan dan ketaqwaan terhadap seluruh aspek kehidupan kepada peserta didik. Seperti pembacaan ayat suci Al-Qur'an sebelum belajar atau menghafal surah-surah pendek di sekolah umum. Ketiga, Dan untuk di perguruan tinggi dapat di ubah yang awalnya perguruan tinggi agama( IAIN atau STAIN) menjadi UIN yang mencakup segala aspek ilmu umum dan ilmu agama. Keempat, Mengutip dari perkataan Fazlur Rahman salah satu pendekatannya adalah dengan menerima pendidikan sekuler modern sebagaimana telah berkembang secara umum di dunia

\footnotetext{
9 Akhmad Said, "Problematika Pendidikan Agama Islam di Sekolah dan Perguruan Tinggi", Jurnal Ta'limunan volume 2, No, 2, September 2013, hlm.101

10 Pemerintah RI, Undang-undang Nomor 20 Tahun 2003 tentang Sistem Pendidikan Nasional, ( Jakarta: Depdiknas,2003)
} 
Barat dengan mencoba memasukan konsep-konsep ajaran Islam. Mengutip dari perkataan Al-Faruqi ia menawarkan islamisasi ilmu dalam pendidikan dengan cara menggabungkan dua sistem pendidikan tradisional dan modern menjadi suatu sistem pendidikan yang berwawasan Islam.

\section{Kesimpulan}

Dari uraian diatas dapat disimpulkan bahwa dikotomi berasal bahasa Inggris "dichotomy" yang berarti pembagian dalam dua bagian, pembelahan dua, bercabang dalam dua bagian. Dalam penerapan dikotomi ilmu itu disebutkan sebagai ilmu umum dan ilmu Islam, pendidikan umum dan pendidikan Islam, guru pendidikan umum dan guru pendidikan Islam, sekolah umum dan sekolah Islam. Dan dengan adanya sistem dikotomi ini pun timbulah permasalahan yang disebabkan oleh dikotomi itu sendiri seperti memilah ilmu umum dengan agama dan pembedaan yang menanggung jawabi ilmu agama oleh Departemen Agama dan ilmu umum oleh Dinas Pendidikan. Dan tentunya memiliki solusi yang harus ditempuh ialah menyatukan terminologi ilmu umum dengan agama serta memasukan keagaaman pada semua mata pelajaran/mata kuliah disekolah maupun perguruan tinggi, menerapkan sistem di madrasah dan merubah perguruaan tinggi berbasis agama mennjadi universitas agama negeri.

\section{DAFTAR PUSTAKA}

Echols.John,M, dan Hasan Shadily.2007. "dichotomy”, Kamus Inggris-Indonesia. Jakarta: PT. Gramedia Utama.

Departemen Pendidikan Nasional.2008. Kamus Besar Bahasa Indonesia, edisi keempat. Jakarta: Gramedia Pustaka Utama.

Praktiknya, Ahmad Watik.1991. Pendidikan Islam di Indonesia Antara Cita dan Fakta. Yogyakarta: Tiara Wacana.

Al-Faruqi, Isma'il Raji.1982. Islamization of Knowledge: General Principles and Workplan. Hemdon: HIT.

Abdullah, Amin dkk.2003. Menyatukan Kembali Ilmu-ilmu Agama dan Umum: Upaya memperrtemukan Epistemologi. Yogyakarta: SukaPress.

Haught.2005. Perjumpaann Sains dan Agama: Dari Dialog ke Konflik. Jakarta: Mizan.

Said, Akhmad."Problematika Pendidikan Agama Islam di Sekolah dan Perguruan Tinggi”, Jurnal Ta'limuna volume 2, No, 2, September 2013.

Pemerintah RI.2003. Undang-undang Nomor 20 Tahun 2003 tentang Sistem Pendidikan Nasional. Jakarta: Depdiknas 